Population Pressure and the Future of Western Civilization in Europe Author(s): E. W. Hof stee

Source: The American Journal of Sociology, Vol. 55, No. 6, (May, 1950), pp. 523-532

Published by: The University of Chicago Press

Stable URL: http://www.jstor.org/stable/2771764

Accessed: 06/08/2008 10:09

Your use of the JSTOR archive indicates your acceptance of JSTOR's Terms and Conditions of Use, available at http://www.jstor.org/page/info/about/policies/terms.jsp. JSTOR's Terms and Conditions of Use provides, in part, that unless you have obtained prior permission, you may not download an entire issue of a journal or multiple copies of articles, and you may use content in the JSTOR archive only for your personal, non-commercial use.

Please contact the publisher regarding any further use of this work. Publisher contact information may be obtained at http://www.jstor.org/action/showPublisher?publisherCode=ucpress.

Each copy of any part of a JSTOR transmission must contain the same copyright notice that appears on the screen or printed page of such transmission.

JSTOR is a not-for-profit organization founded in 1995 to build trusted digital archives for scholarship. We work with the scholarly community to preserve their work and the materials they rely upon, and to build a common research platform that promotes the discovery and use of these resources. For more information about JSTOR, please contact support@jstor.org. 


\title{
THE AMERICAN JOURNAL OF SOCIOLOGY
}

Volume LV

MAY 1950

Number 6

\section{POPULATION PRESSURE AND THE FUTURE OF WESTERN CIVILIZATION IN EUROPE*}

\author{
E. W. HOFSTEE
}

\begin{abstract}
Superficially, population pressure may not seem a problem which will concern western Europe in the future, since, for the most part, it shows a net reproduction rate of less than $I$, and before long the population will probably decrease. In reality, population pressure threatens western Europe perhaps more than ever before because the needs of the population are growing and the proportion between population and available resources will probably be less favorable than in the past.
\end{abstract}

Those who know something about the demographic situation in western Europe ask whether there is still some sense in speaking about population pressure in relation to the future of Western civilization. Anyone acquainted with the excellent studies published during the past few years by American authors on population problems in Europe will certainly have drawn the conclusion that, generally speaking, western Europe will not show an increase of population of any importance henceforth. Probably the time of decrease is near. In Europe's Population in the Interwar Years, Dudley $\mathrm{Kirk}^{1}$ publishes a map in which is indicated for the different parts of Europe the net reproduction rate according to Kuczynski. It shows that before the last war it had already diminished in the greater

* This paper was read at the summer course, "The Future of Western Civilization," given for foreign and Dutch students at the University of Utrecht, Holland, in 1949 .

1 Dudley Kirk, Europe's Population in the Interwar Years (Geneva: League of Nations, 1946). part of western Europe to a level of less than $\mathrm{I}$, which means that, if the situation does not change considerably, the population of western Europe will not be able to maintain its present number. Notestein et $a .^{2}$ have come to the same conclusions in their study of the future population of Europe and the Soviet Union. They calculate that the population of western $\mathrm{Eu}$ rope has already almost reached its maximum and that it will decrease before long.

Before trying to answer the question mentioned above, it is necessary to determine exactly what population pressure is, what its origins are, and what dangers lie in it.

Population pressure can be defined as the "social tension originating from an absolute or relative disproportion between population and available resources." An absolute disproportion exists when the proportion is such that it endangers the provision for the

2 Frank W. Notestein et al., The Future Population of Europe and the Soviet Union (Geneva: League of Nations, I944). 
minimum needs of the population and thereby endangers the lives of a considerable part of the population, as is the case in different parts of Southeastern Asia. We can take it for granted that such a proportion will always cause dissatisfaction, even though it may not lead to collective action. A relative disproportion exists if, without in reality endangering the provision for the minimum needs, the people react upon it with a feeling of disastisfaction.

It is clear that we have to understand by "population pressure" something else than overpopulation in the strictly economic sense. Overpopulation in the economic sense comes into being when the density of population rises above the optimum density, i.e., above the density at which the proportion between population and resources is such as to bring the population in question the highest possible prosperity. The density of population in a given country can differ considerably from the optimum density without causing social tensions, that is, without causing population pressure. Population pressure exists only when, by the population as a whole or by a considerable part of it, the proportion between population and resources is consciously or unconsciously felt as a mental or material burden. As is pointed out, too, by Kulischer ${ }^{3}$ and by Thompson, ${ }^{4}$ the population pressure is a phenomenon that cannot be determined by statistical data only; the subjective feeling of the people in question is of paramount importance.

It is necessary to emphasize that population pressure, where it exists, will not always be felt as such, that is, as an unsatisfactory disproportion between resources and population. Only in an uncomplicated agrarian society will this disproportion be felt directly, viz., as a disproportion between the available land and the number of people which must get a living from it.

3 Eugene M. Kulischer, Europe on the Move (New York: Columbia University Press, I948).

4 Warren H. Thompson, Population and Peace in the Pacific (Chicago: University of Chicago Press, 1947).
In modern countries, with well-developed industry and trade, the disproportion will be felt as permanent unemployment or as a standard of living considered insufficient by the people. The consequent dissatisfaction in these countries will be distinguished with difficulty from tensions originating from other causes. In general, the mass of the population will hardly be aware that its feeling of dissatisfaction has something to do with this disproportion unless this is pointed out by its leaders. So it is clear that there was a considerable population pressure in Germany between the two world wars, but it was only through the propaganda of the Nazis that the desire for more Lebensraum became common among the German people.

This ignorance of the background of existing social tensions does not make them less serious, and especially in modernly developed countries a heavy population pressure can cause situations which are not only an internal danger but a threat to international peace as well.

Population pressure can come into being from many causes. Generally speaking, in a more or less stable society population pressure will not manifest itself easily. Conditions that remain long unchanged will generally be considered as normal by the social group in question and will not cause strong reactions. This holds, too, for the proportion between population and resources and the phenomena related to this. If the population increases little or not at all, if the resources remain about the same, if there are no changes in the economic system or in the technical possibilities, etc., the proportion between population and resources will not be felt as a burden even if it differs considerably from the proportion which would be optimal in the economic sense. Population pressure will come into being when a certain social group or its available resources are changing to such a degree that the proportion between population and resources is no longer adjusted to the felt needs. So, population pressure can be con- 
sidered as the consequence of a not yet successful readjustment to new conditions. The most important influences which, on the one side, compel a people to a readjustment and, on the other side, determine the possibility of this readjustment-influences on which, therefore, the existence of population pressure depends-are the following: (I) the development of the number and composition of the population, especially the age composition; (2) the natural conditions for the development of resources; (3) the political and economic conditions, which influence the availability of resources; (4) the availability of capital needed for the exploitation of existing resources; (5) the development of organization of economic life; (6) the technological development; (7) the development of the opinion about an acceptable standard of living.

I may recall briefly the development of the situation in western Europe during about the last one hundred and fifty years. In the nineteenth and the first part of the twentieth century we were confronted in Europe with an enormous increase of the population, caused by the diminishing death rate. By different means Europe succeeded in readjusting itself to the consequences. In the first place, it was possible by improvement of the techniques and organization of economic life to exploit the resources existing inside western Europe (e.g., agriculture) much more efficiently than before and to develop new resources. In the second place, Europe succeeded in developing, to a very great extent, resources outside Europe. In tropical and other territories overseas the production of raw materials and food was developed with the help of European capital, techniques, and organization. For a considerable part these products from overseas went to Europe in exchange for exported products of European industry and as a reward for labor done by Europeans. In the third place, millions of Europeans emigrated during the nineteenth century, especially to the United States. Finally, especially since the end of the past century, the decline of the death rate was counterbal- anced more and more by a decline of the birth rate, so that the surplus of births, which rose sharply in most countries during the nineteenth century, decreased gradually. But what is the present situation and what can be expected in the future? Answering this question requires an analysis of the factors which influence the coming into being of population pressure. A complete analysis in this paper is impossible, but a general survey follows.

\section{NUMBER AND COMPOSITION OF THE POPULATION}

As was pointed out above, at first glance the present demographic situation seems to hold hardly any menace for the future, in view of the decline of population which we may expect before long. But this superficial impression is not right in all respects.

In the first place, it should be emphasized that, especially in countries with a considerable development of industry and trade, the existence of population pressure is not determined in the first instance by the proportion between the total population and the resources but by the number of people who seek employment. This number is to an important degree dependent on the age composition of the population. The caculations of Notestein et al. show us that during the coming years the age composition of the western European population will change to such a degree that, even if after some time the total number of the population should decrease, the number of those who want work-the age group of $\mathrm{I}_{5}-65$ years-will still increase. Taking Europe west of the Iron Curtain as a whole, there must be created in the coming ten to fifteen years some millions of new subsistences to give employment to all who ask for it.

In the second place, we must take into account that under existing conditions it is only relatively correct to speak about the problem of population pressure in western Europe as a whole. In spite of all good intentions, western Europe is still a complex of independent states which pursue their 
own economic and social policies and look first to their own interests. But demographic conditions in the different western European countries are not identical, and, if the political situation in Europe does not change, each will have to solve its demographic problems for itself. Some countries will have little difficulty and will perhaps have to do rather with a shortage of people than with a surplus; others will be confronted with very serious problems. The number of people between ${ }_{5} 5$ and 65 years in Belgium, according to Notestein and others, will decrease between 1945 and 1960 by 40,000 , while in Holland, which today has about as many inhabitants as Belgium, this class will increase by about 900,000 . In reality the difference will perhaps be more, for Notestein underestimated the anticipated increase of the Dutch population.

As long as Europe is not a real economic unit, each country will think only about providing a good living for its own inhabitants and will not trouble to give the surplus population of its neighbor a subsistence, too. Only if there is a shortage of labor for its own economic development will immigration be stimulated. As the practice in Belgium and France shows, for the greater part of the immigrants only the less desired positions, such as those of the miner and the farmhand, are open. If economic unity does not become a complete reality, it is possible that in the near future in some parts of western Europe there will be hardly any population pressure, while in other parts of Europe very dangerous tensions will be brought about, as is already the case in Italy.

In the third place, it should be pointed out that there is danger in the fact that the number of people who will want employment in production will in the near future show irregularities caused by recent fluctuations in the birth rate. This can cause, locally and temporarily, a heavy population pressure, which can lead to a variety of difficulties. Kulischer points out the sharp rise of the number of births in Germany during the Hitler regime, which will cause a rise of the supply of labor be- fore long. Here should be emphasized especially the remarkable phenomenon that in western Europe, already during the war but still more after the war, a sharp rise of the birth rate has come into being. In Holland the number of newborn babies in 1946 and I 947 was about one and a half times as much as in the years before the war. The birth rate is already declining again everywhere, but, nevertheless, in fifteen or twenty years in Holland and several other countries there will be a suddenly increased supply of labor that undoubtedly will cause social tensions. Because of the temporary character of this increased supply, adjustment will be very difficult.

In the fourth place, it is not certain that the suppositions on which the different prognoses of the future population of western Europe are constructed are right. It is diffcult to draw conclusions, now, but there are symptoms pointing to the possibility that the population of western Europe may be more numerous in the future than Notestein calculated. I have already mentioned the rise of the birth rate after the war. A second point, which Notestein could not take into account, is the important migration from east to west, caused by the war, by which, especially, the population of Germany was considerably increased.

Finally, apart from the increase of population in the future, which we still have to expect, conditions in several parts of western Europe are already unsatisfactory. Already before the last war clear symptoms of a population pressure could be observed in several countries, for example, in Italy. That the origin of Word War II can be attributed to such a high degree to population pressure, as it is by Kulischer, may be doubted; but it is a matter of fact that there was a heavy population pressure in Germany, showing itself, for one thing, in the migration to Holland, which was already so densely populated.

\section{THE DEVELOPMENT OF RESOURCES}

Resources are a product of nature and culture. The gifts of nature are resources for mankind only if mankind is mentally 
and socially able to use them for its needs. Oil really became a resource only after the invention of the internal-combustion engine and after society had developed in such a way that this engine could play an important part in economic life. Nature gives the chances; mankind has to develop them. But the natural conditions are primary. If they do not give the chance to meet the demands originating from an increase of the population or rising needs, then social tension, a population pressure, comes into being. What about these natural conditions for western Europe?

Though there is no country in the modern world which depends only on resources inside its own territory and though every country, by means of exchange, has the resources of all parts of the world at its disposal, the resources inside its own territory are of primary importance; the possibilities of exchange, too, are determined to a high degree by the production of its own resources. So, for western Europe, also, the natural conditions in its own territory are of first importance.

It may be sufficient to discuss the natural conditions for the development of the two most important resources, agriculture and the resources for energy. As for agriculture, the soil is used in western Europe more intensively than anywhere else in the world. By a high development of the techniques of agriculture and by an intensive care for the crops, the output is generally, as compared with that in other parts of the world, extremely high. The average output of wheat per acre in Holland, under normal conditions, is about three times as high as in the United States or Canada. Practically all the land which comes into consideration at all is used for agriculture in western Europe. Even the poorest sandy soils give, by means of an abundant use of fertilizers, substantial crops. As has been pointed out already, it was possible to meet the needs of the increasing population of western Europe, among other things, by raising the agricultural production. Notwithstanding that, Europe during the nineteenth and twentieth centuries became to an ever higher degree dependent for its food supply on other parts of the world. This dependence involves serious difficulties, especially since the war, while the still-increasing population and the increased wants, especially for protective foods, stimulate the demand for food even more than before. Is it possible to enlarge agricultural production in Europe? Extension of the area of cultivated land will hardly be possible, even if we make the greatest efforts, as in Holland through reclamation of the Zuider Zee. Undoubtedly there will still be important discoveries in the field of agriculture, while the technical knowledge of our farmers still can be increased. But it must be doubted very much if such a sharp rise of the output of the land as we have seen during the preceding period will even under the most favorable conditions be possible again. We must not forget that the law of diminishing returns still holds for agriculture! The higher the production, the more difficult it is to raise it still more; precisely because western Europe has already progressed so far, a further improvement will be difficult. There are agriculturists who take an even darker view of the future. They are convinced that because of an excessive use of fertilizers and a lack of organic manure the producing qualities of the soil in western Europe threaten to diminish or are already decreased considerably. They point out the increasing number of plant diseases and plagues which attend this forced and very specialized agrarian production and which can be suppressed only by the use of an ever increasing number of poisons. We will have to wait to see whether these pessimists are right, but it seems certainly unjustified to expect that western Europe will be able to provide its own food supply to a higher degree than in the past.

As for the resources for energy, for the present we have practically to do with only three: coal, oil, and hydroelectric power. As for coal, even if some of the most favorably situated coal mines do become exhausted in time, the reserves are large enough to be able to provide for the needs of western Europe, even if these needs should increase. This does not mean that 
the supply of coal for western Europe will bring no difficulties in the near future; but probably these difficulties will originate from the supply of labor and be caused by the unattractiveness of mining, a drawback which perhaps can be reduced by a further mechanization.

Not favorable are the conditions as to the possibility of the production of oil in western Europe. The geological structure of Europe is such that, in the greater part, the chances for tracing oil are completely nil, while the rest is to be considered as promising little, even though the painstaking exploration during and after the war gave some results. Yet in western Europe the progress of economic life becomes more and more dependent on oil, and, therefore, it has to rely for its supply of energy on overseas countries more than ever before. Indeed, it is possible to convert coal into liquid fuel, but apart from the difficulties, already mentioned, which will perhaps arise with regard to the supply of coal, there is the fact that synthetic oil is still extremely expensive, so that if western Europe had to solve the problem of oil supply in this way it would be in an unfavorable position as compared to the countries with natural oil wells at their disposal.

As for hydroelectric power, the possibilities in this respect are not yet exhausted, but they are by no means sufficient to provide for the increasing needs of energy of western Europe.

An inspection of the other resources would lead us to similar results, and generally the conclusion may be drawn that natural conditions are not such that western Europe can rely in the future on its own resources to a much higher degree than in the past.

\section{POLITICAL AND ECONOMIC CONDITIONS}

Therefore, if Europe is to maintain a fair level of prosperity in the future and if it wants to prevent a heavy population pressure from being felt, then it will have to rely to a high degree on resources outside its own territory; and so it is of paramount importance that these foreign resources be politically and economically accessible to western Europe. In the past these resources were politically accessible because a great number of the countries where they were found were brought into some form of political dependence upon western Europe, or, as far as they were independent (e.g., the states of South America), the governments did not hamper the exploitation of the resources for the benefit of western Europe. Economically the resources were accessible because western Europe exported commodities to these territories and west Europeans worked there, in return for which were received all sorts of products which western Europe itself supplied in insufficient measure. We can take it for granted that the political dependence of a considerable part of the world upon western Europe has gradually come to an end. This fact does not necessarily mean that the resources in the territories in question become inaccessible, for Europe did profit, too, from the resources of the independent countries. But often there exists among these newly independent peoples a strong economic nationalism. They try to transform themselves from suppliers of raw materials into industrial countries and so to exploit their resources only for themselves. They try, also, as soon as possible to take over positions in economic life which were held formerly by Europeans; in brief, they try to make themselves independent of the services, commodities, and capital of western Europe, and by doing that they take away the foundations of the system of exchange, which made it possible to exploit these foreign resources for the benefit of western Europe. Moreover, in many cases political independence leads to unstable conditions (Burma, Philippines, Indonesia), by which the exploitation of resources generally is hampered very much. In several countries that were already independent which of old acted as suppliers of food and raw materials for Europe we see, too, a strong aspiration for economic 
independence and for loosening of economic ties with Europe. Of this, Argentina is a clear example. On the other side, Canada gives the example of a development in the direction of an independent and all-round economic life which is coupled with the maintenance of close economic relations with the Old World and the opening of its own resource for the providing for the needs of Europe.

It is still difficult to express a definitive opinion, but it sems probable that Europe will have much more trouble in the future in getting the resources which it needs for its development from outside its own territory than was the case in the past.

\section{THE AVAILABILITY OF CAPITAL}

Apart from labor for the exploitation of existing resources, capital is needed. In the past century western Europe showed a permanent increase of the available amount of capital, by which it was possible, on the one side, to meet the rising needs caused by the increase of the population, while, on the other side, the new technical possibilities could be realized, and so the level of prosperity could be raised. This more or less regular and gradual growth of capital was twice interrupted seriously during the past decades by a world war. Not only was a large quantity of capital destroyed by the wars directly, but during them and in the first years after them the necessary extension and renovation of capital was stopped, and by this the arrears increased. The destruction of capital due to World War II, directly as well as indirectly, was enormous, and, notwithstanding the great amount of labor which has already gone into rehabilitation, the exploitation of the resources of western Europe is still hampered to a high degree by lack of capital.

To bring the supply of capital in this part of the world to an adequate level again and to maintain for the population an acceptable standard of living, western Europe was compelled to sell a considerable part of its foreign investments. An example is the sale of the Argentine railways by England. But the liquidation of these foreign investments was not at all sufficient to solve the problems, and only by the granting of credits by foreign countries, especially by the United States and lately by the ERP (the Marshall Plan) was it possible to restart gradually the production in Europe and to keep it going. Notwithstanding this help, it will be very difficult to find the capital needed for the exploitation of the available resources, which increases the likelihood of population pressure.

Though the efforts to bring back the capital invested outside Europe as much as possible and to re-establish economic life with this capital must be considered as being right, it is clear that, on the other side, the exploitation of resources outside Europe becomes thereby much more difficult, directly in many cases because, with the withdrawal of capital where it cannot be replaced by other capital, the exploitation of resources is endangered. So the rapid withdrawal of European capital from Argentina without sufficient replacing capital being available certainly contributed to the existing economic difficulties and to the declining exploitation of resources in that country. Where replacing capital is available, as in the case of the sale of Dutch shares in American industries, of course it becomes impossible to use the revenues of this capital to purchase overseas resources.

In another respect, too, the insufficient supply of capital hampers the availability of resources outside Europe. Because of the inadequate supply of raw materials and machinery, the productivity of labor in west European industry is low, and so the costs of production are high. So the sale of products outside Europe becomes difficult, which means generally that the exchange of European commodities against the products of resources outside Europe is hampered.

\section{ORGANIZATION OF ECONOMIC LIFE}

In the foregoing, by "exploitation of resources" was meant the whole process of 
production, transport, working-up, etc., of raw materials until the commodities in their final shape reach the consumer. As already pointed out, the question as to whether some gift of nature becomes an economic resource depends to a high degree on the cultural level reached by a given people; also, the way in which the exploitation is accomplished expresses the whole culture of the people. Of special interest in this connection are the forms of organization of economic life. In the development of new forms of organization adapted to the changing conditions, Europe has achieved exceptional results since the Middle Ages. The organization of modern big industry, the modern organization of transport, modern banking, modern management, which are now spread all over the world and which made possible an exploitation of resources as never before, all originated from Europe. But the danger threatens Europe that by the continued development of the organization of modern economic life it will fall behind, especially as compared with the United States and perhaps with Russia. At the moment the productivity of labor in industry in America is three to four times higher than in western Europe. This is caused not only by the abundance of capital and the richer resources of America but by the better organization of the processes of production in the widest sense. For such commodities as motorcars and aeroplanes America has organized production and sale in such a way that Europe in considerable part has become dependent upon America for them, though the natural conditions, the skill of the laborers, and the technical knowledge are certainly sufficient to equal America in this respect. By this, Europe not only becomes dependent upon American resources but, moreover, often cannot compete with America in foreign markets, whereby the possibility of getting foreign products by means of exchange is reduced.

The most important reason by which in western Europe an organization of economic life in accordance with the possibilities of modern techniques is prevented is the stillexisting division into a great number of sovereign states. By this, production and markets are broken up, an adaptation of the available labor to the natural and economic conditions is prevented, and the combination of capital needed for the establishing of industries which could expand over the whole world is hampered. If Europe is to develop in the future, if it is to raise the exploitation of its own resources as high as possible and organize this exploitation as efficiently as possible, and if it is to get access to the resources elsewhere in the world by an export trade as large as possible, then the promotion of the economic and political unity of Europe is the first necessity.

\section{THE TECHNICAL DEVELOPMENT}

Technical progress can lead to the result that new resources become available which formerly, for technical reasons, were not and that resources which were already available can be exploited with less labor or with less capital than before. The availability of new resources will always lead to a lessening of population pressure, of course; but the possibility of exploiting resources with fewer laborers than before will be an advantage only if the unemployed workers find a field of activity in the exploitation of new resources. If that does not happen, then the prosperity of those who remain engaged in the exploitation of the resources in question will increase; but a number of workers will be permanently unemployed, and exactly this permanent unemployment is one of the most dangerous symptoms of population pressure in modern society.

Undoubtedly, continued technological development will be an advantage in many respects; thus the modest production of oil which developed in Holland after the liberation would have been impossible if the techniques of exploration and production had not progressed so much during the past decades. Indirectly, technological progress will perhaps benefit western Europe if by this more and better products of industry 
can be produced and a more extensive exchange with countries producing raw materials and food can be brought about. But if for one reason or another an extension of this exchange is not possible, then it will not be possible to get more foreign resources, and a technological progress becomes a disadvantage rather than an advantage.

The dangers just mentioned are not only theoretical. In Holland the technological progress in agriculture threatens to lead to problems. After the liberation, a strong tendency to mechanization in agriculture, caused, among other things, by a raising of wages, came into being. The consequence of this tendency will be that a considerable number of workers will be turned out of agriculture. The Dutch economists are racking their brains now about how to increase the export of products of industry to such a degree that, not only for the increasing population, but for this surplus of agricultural workers, too, a living will be created, which means, in fact, to get by this export an access to foreign resources on which this people can base a subsistence.

\section{OPINION ON AN ACCEPTABLE STANDARD} OF LIVING

As already pointed out, in a modern industrial and commercial country the disproportion between population and resources will demonstrate itself in permanent unemployment or in a standard of living which is considered by the population in question to be insufficient. Permanent unemployment will always be felt as unsatisfactory and will lead to social tensions. The question as to whether a given standard of living is considered insufficient is dependent not only on the absolute level of this standard but also on the opinion that the social group itself has formed about an acceptable standard of living. This opinion is generally influenced very much by the standard of living of other social groups with which the group in question compares itself. With the development of modern trade, the group with which one compares one's self has increased permanently. Formerly, a farmer compared himself only with his own kind in his own region. Today he compares himself, too, with the inhabitants of the cities, and he asks for a higher standard of living. As for western Europe as a whole, the contact between the old world and the new becomes closer continually, and we can observe more and more a tendency to take the American standard of living as a yardstick and to consider, in consequence, our own standard of living to be insufficient. This, too, can be a cause for tensions in the near future, which, because they can be solved only by a change in the proportion between population and resources, will accentuate the problem of the population pressure.

Objectively speaking, the conditions in western Europe are much more favorable than in many other parts of the world. But population pressure is only partly a question of objective conditions; it is also, and especially, a question of the subjective experiencing of these objective conditions. Conditions which in Southeastern Asia would be felt as a blessing from heaven would perhaps cause in western Europe social tensions which would disturb the whole world.

There is a fair chance that western Europe will overcome all these difficulties. But this will be possible only if we direct our full attention to them and are inclined, inside Europe as well as outside, to fulfil the conditions which must be fulfilled if we want to offset the threatening danger. The most important condition is the establishment of a real west European unity. But a united Europe, too, will be able to prevent a heavy population pressure only if the world outside Europe will open itself to products and men from Europe. Europe must be enabled to co-operate in the development of resources over the whole world, and it must have the chance to exchange the products of European industry with raw materials and food from overseas territories. European emigrants must be ac- 
cepted in those parts of the world where, In western Europe, at the moment, not a by an extension of the population, the ex- single nation possesses the power to make ploitation of resources could be intensified. a successful war if it is not sure of the help If we do not succeed in solving the prob- of the United States of America or the lems in this way, western Europe will be Soviet Union. But an increasing population a danger spot for the world. Authors like pressure can lead certainly to internal unThompson and Kulischer emphasized the rest, which could be the beginning of a great dangers which population pressure in some parts of the world holds for peace. It does not seem probable that an unfavorable development in western Europe in the next years will be a direct cause of a new war. dangerous political development threatening the cultural values of the whole of Western civilization.

Agricultural University of Wagentingen HoLIAND 